\title{
MICROBIOLOGY OF POLLEN AND BEE BREAD : THE GENUS BACILLUS
}

\author{
Martha GILLIAM \\ U.S. Department of Agriculture, Science and Education Administration \\ Carl Hayden Bee Research Center \\ 2000 East Allen Road, Tucson, Arizona 85719
}

\begin{abstract}
SUMMARY
Forty-one bacteria belonging to the genus Bacillus were isolated from almond, Prunus dulcis $(=P$. amygdalus $=P$. communis), pollen from the flower; from pollen pellets from traps placed on hives of honey bees, Apis mellifera, in the almond orchard; and from pollen stored in the comb cells of the hive (bee bread) for one, three, and six weeks. Thirty-three of the 41 isolates were $B$. subtilis, the only species associated with all pollen and bee bread samples. Bacillus megaterium, B. licheniformis, B. pumilus, and B. circulans were also isolated. Since the greatest number of Bacillus isolates and species were found in pollen from the trap, the foraging bees may have added the organisms to the pollen.
\end{abstract}

\section{INTRODUCTION}

Recently, as the first effort in an attempt to define the microflora of pollen and bee bread, I isolated and identified 113 yeasts from almond, Prunus communis, pollen from the flower; from pollen pellets removed from the bees' legs by traps placed on hives of honey bees, Apis mellifera, in the orchard; and from pollen stored in comb cells of the hive (bee bread) for one, three, and six weeks (GILliam, 1979). Torulopsis magnoliae was the most common isolate and was apparently added to pollen by the bees since it was found in all samples except from the flower. The number of isolates and species decreased with time and storage, and most of the yeast species from pollen from the flower and the trap were not found in bee bread. In addition, yeast isolates from pollen from the flower and the trap fermented more sugars and assimilated more carbon compounds than those from bee bread. 
The second effort was concerned with Bacillus organisms associated with pollen and bee bread. Members of the genus Bacillus are rod-shaped bacteria that are capable of forming endospores aerobically. These organisms are commonly associated with worker honey bees (EL-LEITHY and EL-SibAEI, 1972; Gilliam and Valentine, 1976; Gilliam and Morton, 1978). Also, Egorova (1971) found that species of Bacillus accounted for $17 \%$ of the microorganisms that she isolated from bee bread. However, though these isolates had proteolytic enzymes, they did not participate in the lactic fermentation that has been reported to be responsible for the conversion of pollen to bee bread (Chevtchik, 1950; PAIN and Maugenet, 1966). Otherwise, little work has been conducted on members of the genus Bacillus found in pollen and bee bread. WHITE (1906) found that pollen stored in the cells of combs containing European foulbrood contains many B. alvei organisms. CHEvTCHIK (1950) reported that sporulating aerobic bacteria, lactic acid bacteria, yeasts, and indole-producing bacteria were present in pollen at the time the fermentation began. Also, MACHADO (1971) reported an interesting association between the pollen of Melipona quadrifasciata and a Bacillus organism. The Bacillus appeared to predigest the pollen, and elimination of the organism caused destruction of the comb cells by the workers and the eventual death of the colony.

Reported here are the results of the examination of pollen and bee bread for organisms belonging to the genus Bacillus. These organisms are known for their ability to produce antibiotics (KATZ and DEMAIN, 1977); terminally methyl-branched fatty acids (KANEDA, 1977); and numerous enzymes (BAPTIST et al., 1978) including pectinases (LAJUdie and Dumanoir, 1976), cellulases (SERzedello and TAuK, 1974), and commercially significant enzymes such as amylases, proteases, $\beta$-glucanases, and isomerases (FOGARTY et al., $1974 \mathrm{a}, 1974 \mathrm{~b}$ ). Because of the wide range of metabolic activities of these organisms, they may be important in the production and preservation of bee bread.

\section{MATERIALS AND METHODS}

Details of methods used to collect and preserve almond pollen and to establish and maintain the bee colonies that received the packed almond pellets are given by Gilliam (1979). Samples were pollen from the flower and from the bees' legs and bee bread stored in comb cells for one, three, and six weeks. Each pollen and bee bread sample was divided into four sub-samples of approximately $0.75 \mathrm{~g}$ each. Then each of the four sub-samples was homogenized by hand in $2.5 \mathrm{ml}$ of $0.85 \% \mathrm{NaCl}$ in a glass tissue grinder. The homogenates were plated $(0.1 \mathrm{ml})$ in duplicate on nutrient agar acidified with $0.1 \mathrm{~N} \mathrm{HCl}$ to $p \mathrm{H} 5$ and eugon agar $(p \mathrm{H} 7)$ (Difco) (1). One plate from each sub-sample on each medium was incubated at $26^{\circ} \mathrm{C}$ and one at $37^{\circ} \mathrm{C}$ under aerobic conditions. Thus, 16 plates were streaked with each sample for a total of 80 plates in the experiment. When bacterial colonies appeared, they were restreaked on plates of the medium used for the initial isolation to test for pure cultures. These plates were incubated at $37^{\circ} \mathrm{C}$.

(1) Mention of a proprietary product in this paper does not constitute an endorsement of this product by U.S.D.A. 
All colonies were stained by the Gram method and examined for spores. The size. shape, and location of the spores within the sporangia were noted, and the morphology of the vegetative cells was determined. Although most cultures contained sporangia and free spores after incubation for $\mathbf{4 8}$ hours, a few had to be incubated for as long as 12 days before observations could be made. Those organisms belonging to the genus Bacillus were maintained on slants of nutrient agar. They were tested and identified according to GORDON et al. (1973).

\section{RESULTS AND DISCUSSION}

Five species belonging to the genus Bacillus were isolated from pollen and bee bread by the sampling procedure used (Table 1). Of the 41 isolates, 33 were $B$. subtilis. (The atypical isolates of $B$. subtilis did not hydrolyze starch or decompose casein but were identical to $B$. subtilis in all other respects and thus were assigned to this species.) Bacillus subtilis was the only species associated with all pollen and bee bread samples. possibly because of some role of the organism in the elaboration of bee bread and/or because of the ability of the organism to survive in this particular environment. Bacillus megaterium, B. licheniformis, B. pumilus, and B. circulans were also isolated. All of the organisms isolated have been found in the guts of worker honey bees in Arizona (Gilliam and Valentine, 1976; Gilliam and MORTON, 1978).

Only $B$. subtilis was found in pollen from the flower. Since the greatest number of Bacillus isolates and species were found in pollen from the trap, the foraging bees may have added these organisms to the pollen when making a suitable mass to carry back to the hive. With time, the number of isolates and of species represented decreased.

Comparison of isolations from pollen and bee bread revealed that 25 organisms were from pollen from the flower and from the bees' legs. and 16 were from bee bread. All of the organisms identified were found in both pollen and bee bread except that $B$. circlilans was isolated only from pollen.

All of the isolates fermented $\mathrm{D}(+)$-glucose with acid production only and produced catalase. All but the one B. circulans grew at $p \mathrm{H} 5.7$, grew in $7 \% \mathrm{NaCl}$, and liquified gelatin. Ninety-eight percent of the isolates fermented $(D(+)$-xylose and $D(-)$-mannitol with acid production only. Ninety percent produced acetymethylcarbinol and reduced nitrates to nitrites, $83 \%$ fermented $\mathrm{D}(+)$-trehalose with acid production only, and only $39 \%$ fermented $\mathrm{L}(+)$ arabinose with acid production. Also, $80 \%$ hydrolyzed starch, $78 \%$ decomposed casein, and $85 \%$ used citrate as the sole carbon source. Thus, these organisms produced proteolytic enzymes and amylases, fermented carbohydrates, grew at acid $p \mathbf{H}$, tolerated high osmotic pressure, and reduced nitrates to nitrites.

Although Bacillus spp. were much less numerous than yeasts (Gilliam, 1979) in pollen and bee bread, they may be important because of their many metabolic activities. LAvie (1960) found that pollen collected by bees contains an active 
TABL. 1. - Bacillus isolated from almond pollen and bee bread.

\begin{tabular}{lc}
\hline Organism & $\begin{array}{c}\text { Number of } \\
\text { isolates }\end{array}$ \\
\hline
\end{tabular}

Isolates from pollen from the flower

Bacillus subtilis

Isolates from pollen from the bees' legs (pollen trap)
B. subtilis
B. subtilis (atypical)
B. megaterium
B. licheniformis
B. circulans

B. subtilis

Isolates from bee bread stored in the comb for 1 week

Isolates from bee bread stored in the comb for 3 weeks

B. subtilis

B. pumilus

B. subtilis

3. licheniformis

Isolates from bee bread stored in the comb for 6 weeks

a From a total of 80 plates in the experiment.

antibiotic factor that is derived both from the bee and the plant, and this factor was active against $B$. alvei and $B$. larvae but had no anti-fungal properties. Thus, it may limit the numbers and species of Bacillus without affecting the yeasts. In any case, it appears that a specific microflora does occur in pollen and bee bread, and it is particularly noticeable in regard to Bacillus spp. Moreover, 66 different peptide antibiotics are produced by strains of $B$. subtilis, and most of these are active against gram-positive bacteria though some are active against yeasts and molds (BERDY, 1974). Thus, the picture becomes quite complicated.

If lactic acid preserves stored pollen by the same process that occurs in green food materials stored in silos (HAYDAK, 1958), some analogies may be drawn from what is known of the role of Bacillus in silage. For example, bacteria of the genus Bacillus, yeasts, and molds affect the stability of silage on its removal from the silo for feeding (WOOLFORD, 1978). Also, Bacillus organisms apparently have the ability to contribute to the lactic acid and acetic acid content of silage. However, they do not contribute to the same extent as the lactic acid bacteria, and they are less efficient than lactic acid bacteria in the production of lactic acid from water-soluble carbohydrates 
(WoOLFord, 1977). However, at this time the role of these organisms in pollen and bee bread is unknown. Only additional experimental work will elucidate the contributions of micro-organisms to the nutrition of honey bees.

\section{ACKNOWLEDGEMENT}

I thank Dr. L. N. StANDIFER for the pollen samples.

Received for publication in April 1979.

\section{ZUSAMMENFASSUNG}

\section{MIKROBIOLOGIE VON POLLEN UND BIENENBROT :}

DAS GENUS BACILLUS

Die folgenden Proben von Mandelpollen (Prunus dulcis $=P$. amygdalus $=P$. communis) wurden auf das Vorkommen von aerobischen, sporenbildenden Bakterien aus dem Genus Bacillus untersucht:

- handgesammelter Pollen aus den Blüten;

- Pollen, der mittels Pollenfallen an Völkern in Mandelpflanzungen von den Beinen der Bienen abgestreift worden war;

- Pollen in Wabenzellen (Bienenbrot), der dort eine, drei oder sechs Wochen lang gelagert war.

Homogenate von jeder Probe wurden auf Platten mit saurem Nähragar $(p \mathrm{H} 5)$ und Eugon-Agar (pH 7) ausgebracht.

41 Bakterien aus dem Genus Bacillus wurden isoliert und bestimmt. 33 von den Isolaten waren $B$. subtilis, die einzige Art, die in allen Proben von Pollen und Bienenbrot vorkam. Ausserdem wurde Bacillus megaterium, B. licheniformis, B. pumilus und B. circulans isoliert. Da die grösste Zahl von Bacillus-Isolaten und -Arten in Pollen aus der Falle gefunden wurde, könnte es sein, dass diese Organismen durch die Sammelbienen in den Pollen gelangten.

Obwohl Bacillus-Organismen im Pollen wesentlich weniger häufig waren als Hefen, können sie doch wegen der Breite ihrer Stoffwechselaktivitäten - z.B. in der Produktion von Antibiotika und Enzymen von Bedeutung sein.

\section{RESUME \\ MICROBIOLOGIE DU POLLEN ET DU PAIN D'ABEILLES : LE GENRE BACILLUS}

On a recherché les bactéries aérobies sporulantes appartenant au genre Bacillus dans les échantillons suivants de pollen d'amandier, Prunus dulcis $(=P$. amygdalus $=P$. communis) : pollen récolté à la main sur les fleurs; pollen prélevé sur les pattes d'abeilles, Apis mellifera; des trappes placées sur les ruches situées dans le verger d'amandiers; et pollen stocké dans les cellules des rayons de la ruche (pain d'abeilles) pendant 1 semaine, 3 ou 6 semaines. Des homogénats de chacun des échantillons ont été déposés sur agar nutritif acidifié ( $p \mathrm{H} \mathrm{5)}$ et sur agar eugon ( $p \mathrm{H} \mathrm{7)}$.

Quarante et une bactéries du genre Bacillus ont été isolées et identifiées. Trente-trois d'entre elles étaient Bacillus subtilis, seule espèce associée à tous les échantillons de pollen et de pain d'abeilles. On a 
également isolé B. megaterium, B. licheniformis, B. pumilis et B. circulans. Puisque le plus grand nombre de bactéries isolées et d'espèces a été trouvé dans le pollen provenant de trappes. on peut supposer que ce sont les abeilles butineuses qui ont ajouté ces organismes au pollen.

Bien que les organismes de type Bacillus soient bien moins nombrcus dans le pollen que les levures, ils peuvent avoir un rôle important à cause du large domaine de leurs act it its metaboliques. telles que la production d'antibiotiques et d'enzymes.

\section{REFERENCES}

Baptist J. N.. Mandel M., GhFrna R. L.. 1978. - Comparative zone electrophoresis of enzymes in the genus Bacillus. Int. J. Sist. Bacteriol. 28, 229244.

BERDY J.. 1974. - Recent developments of antibiotic research and classification of antibiotics according to chemical structure. Adr. Appl. Microbiol, 18, 309.406.

Chevrchik V., 1950. - Mikrobiologie pylového kvašeni. Publ. Hac. Sci. Lnir. Masary.k, 323, $103-130$.

Egorova A. I., 197I. - |Preservative microflora in stored pollen.| Jeterinarila, 8, 40-41.

El-Leithy M. A., El. Sibaei K. B.. 1972. - External and internal microflora of the honey hees (Apis mellifera L.). Egupt. J. Microbiol., 7, 7987.

Fogarty W. M., Griffin P. J.. Joyce A. M.. 1974. - Enzymes of Bacillus species-part 1. Process Biochem. 9, $11.18,24$.

Fogarty W. M., Griffin P. J., Joyce A. M., 1974. -- Enzymes of Bacillus species-part 2. Process Biochem., 9. 27-29.31.33. 35.

GII I. MM M. 1979. - Microbiology of pollen and bee bread : the yeasts. Apidologic, 10, 43.53.

Gilliam M.. Morton H. L., 1978. -- Bacteria belonging to the genus Bacillus isolated from honey bees. Apis mellifera, fed 2.4-D and antibiotics. Apidologie, 9, 213221.

Gilifam M., Valfntine D. K.. 1976. -- Bacteria isolated from the intestinal contents of foraging worker honey hees. Apis mellifera: the genus Bacillus. J. Imeriebr. Pathrl., 28, 275276.

Gordon R. E., Haynes W. C. Hor-Nay Pang C. 1973. - The genus Bacillus. USDA Mandbook, 427 .

HAYDAK M. H., 1958. - Pollen-pollen substitutes bee bread. Amer. Bee J., 98, 145-146.

KANEDA T., 1977. - Fatty acids of the genus Bacillus: an example of branched-chain preference. Bacteriol. Rev., 41, 391-418.

Katz E., Demain A. L., 1977. -- The peptide antibiotics of Bacillus : chemistry, hiogenesis. and possible functions. Bacteriol. Rel.., 41, 449-474.

Lajudie J., Dumanoir V. C., 1976. - Recherche de l"activite pectinclytique chez le genre Bacillus, Ann. Microbiol. Inst. Pasteur, 127 A, 423-427.

LAviE P.. 1960. - Les substances antibactériennes dans la colonie dabeilles (Apis mellifera L.). Ann. Abeille, 3, $103183,201-305$.

Machado J. O., 1971. ... Simbiose entre as abelhas sociais brasileiras (Meliponinae, Apidae) e uma especie de bacteria. Ciencia e Cultura (Sao Paulo), 23, 625-633.

PAIN J.. MAUGENFT J., 1966. - Recherches biochimiques et physiologiques sur le pollen emmagasiné par les abeilles. Ann. Abeille, 9, 209.236.

Serzedello A., Tauk S. M., 1974. - Cellulase de bactérias isoladas de "ninhos " de Alta laeligata, Smith. Ciencia e Cultura (Sao Paulo), 26, 957.960.

White G. F.. 1906. - The bacteria of the apiary. ESDA Tech. Series, 14, 1.50.

WOOJ.FORD M. K.. 1977. - Studies on the significance of three Bacillus species to the ensiling process. J. Appl. Bacteriol., 43, 447-452.

WOOLFORD M. K., 1978. - Antimicrobial effects of mineral acids. organic acids. salts and sterilizing agents in relation to their potential as silage additives. J. Brit. Grassland Soc.. 33, 131.136. 